\title{
The Development of the Primitive iurisdictio episcopalis
}

\author{
Javier Belda Iniesta, Patricia Blanco Díez \\ Universidad Católica de Murcia (UCAM)
}

The irruption of Christianity in Roman society implied a necessary process of adaptation of both realities, which coexisted in a common political and cultural space. Outside of first incomprehension from both sides - crystallized in groups that, on the one hand, foresaw the imminent Parousia, and the periodic violent reactions against this weird group of followers of an executed Galileo, on the other hand - truth is that both parts must have little by little adapted to a cohabitation they saw themselves headed toward, since they shared a common space. In turn, Christians, no matter their diverse origin, social or geographical, had to become little by little aware of their own identity, building through the years an internal organization that should answer not only to the necessities of this primitive religious society inside the enormous frame of the Empire, but also to some circumstances presented in their own evolution, as they were a particular human group with a clear mission — Gospel preaching — and with very specific sources they could not separate from. Within these organization needs, one of them was the administration of Justice, needed in all societies, and clearly articulated in the Roman world, but completely distant from the evangelic principles that must guide every action of a Christian. There begins the difficult task of constructing an organization able to answer to the needs of the community and to the mission given by Jesus, doing this task, firstly, in parallel to the Empire, and later under its protection. However, this will not mean the abandonment of the authority due to the established political power, but a complicated combination between obedience toward the authorities and the application ad intra of a Law in accordance with the condition of being "saved" of the believers, whose starting point will be, no doubt, the Gospel. It is clear that when both visions collide, that born from the faith should be given priority, but both will be combined as much as possible. Our paper tries to show the relations of the ecclesiastic authority as long as the temporary power was changing, from the end of secrecy to the fall of the Empire and the beginning of Middle Ages. We must take into account that concepts such as potestas, iurisdictio or auctorictas are still in a first state of gestation, not only to the temporary power, that to some extent still conserves the imperial inheritance, but also to a Church that has just left secrecy and must live with an authority that is taking conscience of itself and reaching its age of majority.

Keywords: Iurisdictio episcopalis, Potestas directa, Potestas indirecta, auctoritas episcopalis, relations Empire-Church

\section{Introduction}

Prior to the fall of the Roman Empire, and all the administrative and political organization implied, there was a lack of power where no Roman authority or any other public administration was present, something that entailed a gradual seek of the few structures that still survived in order to find its own identity, as a basis to exercise a truly, authentic authority (Belda Iniesta, 2015). After many centuries of imperial organization, administrations were absolutely lost without anyone exercising control in a clear and undisputed way. That 
circumstance, together with the development lived by the ecclesiastic world since secrecy was abandoned thanks to the decrees of Emperor Constantine (Mommsen \& Meyer, 1990, p. 62), made the people turn to the bishops seeking a strong authority, given that they knew no other superior authority. For years, they have been exercising judicial tasks, and they were an example not only of moral superiority but also of equity and the wish of the well-being of all (Maymot, 1997, p. 165).

However, even though they had such a good reputation, the loss of the centrality of Rome also had serious consequences from the point of view of the primacy of Churches. Many cities will surpass Rome in importance as well as in political power or even in the military one: for so long, Byzantium itself enjoyed a good economic and political health, superior to the Latin one, let alone the fact that there will stand the imperial structures that will favor the centrality of the importance of its capital. So will start a hard process through which the Church, with its central structures incarnated in the bishopric, will fight to find the place it deserves, not only in the acceptance of the people, but only in a political level (Festugiere \& Fabre, 1955, p. 14). All these facts will produce a number of complicated, and sometimes tense, relations that will lead to the raising of awareness of their own authority by all ecclesiastic authorities, as well as of their scope of competence. Evidently, this will not happen immediately, in fact, it will be a long and hard process not exempt of some moments of real danger for the newborn christianitas.

\section{The Transition From the Empire to the Christianitas}

This transition from the roman world and the acceptance of the roman structures by the Church to the new conception that will appear through the Middle Ages, will be a long process of agreements and disagreements between two completely different realities. In fact, the roman heritage is fundamental, from a juridical or social point of view as well as from an ecclesiastic one (Salegui Urdaneta, 2009, p. 54), but at the same time the new support found by the papacy is not strictly a roman descent, but an external one. The political organization of these peoples is fundamentally customary and has nothing to do with the centralist and absolutist organization of the roman world (Ullman, 1983, pp. 9-11). Thus, we find two completely different ways of political organization: on the one hand the ascendant one, typical of the German people, characterized by the creation of the Law - fundamental element to bring together a society — in assemblies and according to the decisions taken by all members; on the other hand, the Roman juridical system, showing an elaborated concept of authority and power based on the divine conception of the imperial authority. The meeting point of these two systems will be the fact that the king will be considered the receiver of the power in the hands of God, a transmission that will be confirmed by the ecclesiastic authority (Mato Ortega, 2003, pp. 20-24).

At the same time, the Episcopal ministry has been developed, receiving some attributions as the result of the theological reflection of the assignment given by Christ, and it will also imply their transformation into new figures that must be taken into account from a political point of view and from a hierarchical one (Belda Iniesta, 2015, pp. 399-401).

From the point of view of the articulation of the power, the Emperor was little by little leaving his function of princeps senatus (Ullman, 1983, p. 11) in order to take the place of the dominus in times of Diocletian. This change will imply the equivalent evolution regarding sovereignty: if before the Emperor received the power directly from the people, in Late Antiquity he will receive it directly from God, exercising the functions of a king and of a priest. Regarding the Christian vision, this step from a principal to a Lord finds an easy theological explanation, as long as there is only one God above, there can only be a Lord in earth. These theocratic 
principles will be reinforced when the capital is taken to Constantinople (Castaños-Mollor, 1981, p. 474)

It is particularly relevant who takes the capital from one place to another. It will be Constantine who starts the integration policies of the Church and the Empire-starting from his mother and his marvelous conversion (Belda Iniesta, 2012) - and the one who will end up by proclaiming himself the Vicar of Christ and the representative of Christ on Earth (OrlandisRovira, 1999, p. 227). This is something that will present some consequences: if what is said by the emperor in the civil domain automatically becomes the law, as the owner of the title of Vicar of Christ, the doctrine also becomes a matter of his authority. This idea of sovereignty will be noted by Justinian, who will base it on History as well as on the sacred acknowledgement of his authority (Reina, 1969, pp. 179-220).

These arguments will imply some problems regarding the jurisdictional point of view and the legal authority, and they will reach their zenith during the Middle Ages. The Church, led by the bishop of Rome, was eminently a roman institution, and therefore, under the imperial jurisdiction (Reina, 1969, pp. 179-220). This situation, obviously, could not be accepted by the papacy, which will show a completely different attitude: since the Empire is Christian, it must submit the supreme authority of Christ, who entrusted Peter and his followers with this mission.

Actually, it is difficult to talk about a problem of iurisdictio, as long as it is not a matter of competences, but an attempt from both sides to hold the same power, and it is not still differentiated one domain from the other at that moment (Baus, Beck, Ewig, \& Vogf, 1972, p. 29). The papacy will argue, in front of the imperial thesis supporting the coronation in the power given by God, that it cannot be claimed what it has been given as its own (Ullman, 1983, p. 12). If the Pope represents Christ, he is at the same time the owner of the tutelage (formulated according to the principle of auctorictas) (Fabrini, 1978, pp. 492-561) over the secular domain, whose ruler will only posses the potestas (García Villoslada, 1963, pp. 294-296).

\section{The potestas indirecta and the ration epeccatii}

In order to obtain a better understanding of which are the reasons adduced by the different groups, we should, first of all, focus on the idea of the potestasindirecta (Reina, 1966, pp. 107-118). Great authors of this issue of the XVIth and XVIIth centuries such as Vitoria, Belarmino, Suárez (Lo Grasso, 1939, pp. 489-490) have analyzed it as a problem of the ecclesiastic power applied to the temporal order. However, this approach implies the acceptance of an indirect responsibility of the temporal order, given that the Church is not the holder of a single power, that is, the spiritual one, and it will not directly touch the human order (Riviere, 1962; Arqulliere, 1965; Maccarrone, 1940; Leclerc, 1959; Stlckler, 1954, pp. 1-26).

Nevertheless, from our point of view, this is not really a matter of definition of competence domains, but a matter of how this sacred power is exercised, being characteristic of the Church, in the temporal domain, as long as the only space to exercise this power is not the temporal world we know.

This trouble of the separation of the direct and indirect power will be aggravated with the fact that different competencies will be transferred, fundamentally from the Church to the secular world, in order to face some problems that, ratione peccati, necessarily implied the exercise of power from the secular world, although it implied some eminently sacred connotations. Then, the conception of the secular arm will be established, even though it is perfectly comprehensible in the historical context in which we move, due to the limited capacity of action of the ecclesiastic hierarchy, it does not have a clear doctrinal basis (Reina, 1966, p. 110). At the same time, we should understand that the temporal power and the spiritual one find in humanity the same 
problems, and the same obligation of answer before God, something that makes the task even more difficult. The Emperor receives such a mission in order to protect the Church: in that sense, the potestas indirecta could be used to clarify the autonomy of the civil power that, not having received the mission from Christ, has some capacity to act.

However, this conception of independency in front of the spiritual authority, when interests and obligations of both parts converge, has ended in a deep confusion of the supernatural order and natural one. This is an issue coming from the times of Augustine, meaning the dichotomy between nature and grace that finally underlies in both authorities (De La Hera, 1965, p. 788).

Although, during the last century, the ambiguity and dependence of the historical context and, therefore, of the circumstances of the moment pulsing at the basis of this theory, have been criticized (Saraceni, 1951, p. 45; Congar, 1952). In turn, REINA report us that LUBAC has stated three fundamental aspects in the critic of the theory of the indirect power:

First of all, the approach implying the dilemma between jurisdiction and direction is not adequate, for it evades the necessary presence of the command in one, whereas in the other one its basis is a moral advice searching some specific effects.

Secondly, even though in occasions it has been a recurrent argument: "No es necesario insister en el error de perspectiva que ha supuestomuchasvecestrasladar la supremacía de lo espiritualcomo base de la supremacía jurídica del poder spiritual sobre el temporal enrazón de losfines" (Maritain, 1947; Reina, 1966, p. 111), adducing that the presence of necessities directly related to the Kingdom of God and, consequently superior, would imply justifying any mean used to reach such goals. This would also leave unsolved the question of the effective or not effective power of the Pope in the temporal domain, since we could not understand the spiritual aspect but inside the human one.

Finally, if the Pope can exercise a temporal authority in some cases, such as those justified by the ratione peccati formula, we would find ourselves before a power that changes dependent on the circumstances, no matter how extreme these could be (De Lubac, 1952, pp. 335-340).

Another one of the aspects that could create different discussions would be the fact that in order to base the sacred power on the temporal domain we would find an unsolved question, and this question is how a decision taken by the sacred power could affect those who are not faithful and, subsequently, do not consider themselves within the spiritual order subject to the supreme authority of the Roman Pontiff.

\section{Potestas and auctoritas}

In order to answer to this question, we should delve into the concepts of power and authority and how they have evolved through the centuries. Professor D'ORS (D’Ors, 1964, pp. 23-35) was the one who, according to REINA, has made one the most accurate contributions in this sense to the juridical science (Reina, 1966, p. 112).

D'ORS will use the simile of the powers of the soul, among which we can distinguish intelligence and will, in order to explain both concepts. Even though when these powers act we perceive them in a combined way, they are still different, finding the same situation in the social domain. Thus, he will say that the authority is the socially acknowledged truth, and the power the socially acknowledged will of the power. Although they are presented in a combined way, the social acknowledgement, common to both of them, is not enough to confuse one and another (D'Ors, 1964, p. 23). The problem, however, is found when we try to move this simile to the 
ecclesiastic hierarchy. In this case, it is much more complex to find the difference, since the ecclesiastic authority, given its sacred character, is the continuation of the intelligence and the will of God (ratio divina vel voluntad Dei). D'ORS solves the problem stating that the hierarchy, even being a divine institution, is made of men, what helps us differentiate both:

En efecto, el alcance de la potestad y de la autoridad no es el mismo, y así, podemos distinguir en el Papa una potestad católica, pero limitada por razón de la materia (lo contrario sería convertir al Papa en un rey universal) y una autoridad realmente universal, que excede de su potestad. Esta autoridad universal es la que aparece en un primer plano cara al mundo. Esto mismo explicaría la naturaleza de aquella que se ha venido llamando "potestas indirecta", y que excede de la potestad propiamente dicha, y que es, en realidad, una especial manifestación de la autoridad universal del Papa. (Reina, 1966, p. 113)

This position, as we see, poses some problems. On the one hand, if the authority is the socially acknowledged truth, and at the same time, the potestas indirecta is a way of showing the universal authority of the Roman Pontiff. If we leave the ecclesiastic domain, we could base the papal authority on questions strictly unconnected to its proper nature. On the other hand, we should also see the fact that, because the mission given by God, the Church not only posses enough authority to transmit the Gospels, but also the power to fix such teachings and the way of transmission of the good news with the authority given by this assignment (Mateo, 16:19). Moreover, we should not forget the problem of the obligation of Christians and non-Christians to the commands of a spiritual authority in the temporal order.

\section{The Problem of the iurisdictio}

Therefore, it is necessary to address the problem related to the jurisdiction (Garroté, 1997, p. 298). The ecclesiastic conception of the iurisdictio came from Roman Law (Corecco, 1968, p. 107), and it was associated to the jurisdictional function of the magistrate who dealt out justice, that is, the capacity of channeling trials and creating new formulas regarding the necessities of the citizens coming to him. Little by little this concept evolved, extending itself from the justice administration (Reina, 1969, pp. 179-220) to all magistrates, whether they exercised judicial task or not (Fabrini, 1978, p. 512). Thus, it will finally imply all competences from the magistracy, creating a federal power, legislative, administrative or judicial, that maintained its organized and hierarchical character and omnicomprehensive at the same time (Fabrini, 1978, p. 512).

This was the concept adopted by the canonistic doctrine over the base of the roman term, producing an evident continuity between both Laws and finally defining the amount of powers exercised by the bishop (Martínez Blanco, 1994, p. 167).

Today, the acceptation of the existence of the Episcopal power during the first centuries of Christendom is common doctrine. The question, then, is not exactly its existence, broadly accepted, but how it will be exercised and who will be its holder: many authors will consider such power as a unique and integral reality, leaving aside the separation of the powers of jurisdiction and its exercise outside the power of order. This position will be defended by scholars like Mörsdorf and Bertrams (Bertrams, 1965, pp. 175-176), and in a material but not formal way, by CORECCO (Corecco, 1985, pp. 64-75). Others, like STICKLER, however, defend the bipartition of the ecclesiastic power.

\section{Jurisdiction as a Unity}

The main defender of the jurisdiction as a unity will be MÖRSDORF (Cattaneo, 1986, p. 383), who mainly in two works (Cattaneo, 1986, pp. 440-441), will present his thought in a gradual way. Actually, Mörsdorf does 
not support that historically only one power is known until well into the XIIth century, but the fact that the elements composing it were so united that it is not possible to find ways to differentiate which ones belong to one or the other (Garroté, 1997, p. 260). He refers to the prohibition by the Council of Chalcedon (451) of the absolute ordinations, making them ineffective. Such absolute ordination could not be exercised in any place. Actually, this prohibition referred to the exercise of ordination, not its validity.

These two elements, consecration and office, will be intimately related and they will be the main reason of the great problems and discussions of the time of reflection in which the Church is contemplating the basis that sustain it. Moreover, until the arrival of Gratian, it will not start to establish the lines that, even not completely solving the problem, at least will show the way to be covered in order to find the solution. Thus, the key to distinguish the two elements lies in the fact that the first one is absolutely indelible and cannot be cancelled by any human power whatsoever, whereas the second one keeps being a canonical mission, and, therefore, a mission that can be revoked by the competent authority (Cattaneo, 1986, pp. 141-142).

Regarding this formal distinction of the origin and the possibility of revocation of both powers, will Mörsdorf build his doctrine, and it will imply the essential element to understand his attitude towards the matter of jurisdiction (Garroté, 1997, p. 261). We can see here that the differentiation between both powers is merely formal for him, and not also material, final and by origin, like in Stickler. The Second Vatican Council will be given this doctrine and will develop it more in depth. In the article De sacra potestate: Quinquagesimo vol venteanniversario a Codice Iuris Canonici promulgato. Miscellanea in honorem Dini Staffa et PericlisFelici S. R. E. Cardinalium I, en «Apollinaris» 40 (1967) 45, Mörsdorf sums up the teachings of the Council considering that the sacred power has its origin in Christ, and it has been exercised in his name in the fulfillment of the ministry that he himself establish in his Church.

We could consider this author, as CATTANEO and GARROTE do, as one the forefathers of the councilor doctrine of the unity of jurisdiction (Cattaneo, 1986, pp. 131-132). Evidently, the doctrine has to think about how this power must be developed and organized, given that the detailed study of its articulation is not the proper field of the magistracy (Mörsdorf, 1967, p. 49).

Following GARROTE (Garroté, 1997, p. 260), we will summarize in three fundamental points the doctrine of MÖRSDORF related to the differences in the unity of the power of jurisdiction and the power of order:

First of all, the author points out that the power of social order is equivalent to a vital principle, whereas the power of jurisdiction would be the organizing principle within the Church (Mörsdorf, 1967, p. 54). Thus: "principium generans - potestad de orden - y principium dirigens - potestad de jurisdicción-. Se trata de dos fuerzas divinas que dan vida a la Iglesia de modo distinto: una como fuerza generadora (zeugende), la otra como fuerza ordenadora (ordnende)" (Mörsdorf, 1967, p. 48).

The next point to summarize the German master is the logic consequence of the development of both principles, posing the same relation found between Word and Sacrament (Celeghin, p. 179): being two diverse ways of administering the Salvation irradiated by the Cross, they form by themselves an inseparable unit:

El anuncio de la Palabra y la administración de los sacramentos son dos modosdiversos de proceder con los cuales la Iglesia comunica la salvación, pero que se encuentran íntimamente unidos entre ellos y forman una unidad operativa porque es el mismo Cristo quien, de estos dos modos, continúa su obrasalvífica. (Cattaneo, 1986, p. 145) 
As we can see, according to MORSDORF, within the Church a dual structure is presented, whose external manifestation will be this distinction between the power of jurisdiction and the power of order as if they were the two sides of the same coin (Garroté, 1997, p. 261). In the same way that the Word cannot live without the Sacrament and the Sacrament is the incarnation of the Word, given that both realities are united in Christ. One requires the consecration, the other the mission canonica, that is, is essentially revocable (Mörsdorf, 1967, p. $53)$.

Finally, the union of both parts is perfectly seen in the case of the bishop, in which his sacramental consecration implies assuming the creation of a new jurisdictional category:

La consagración episcopal constituye - en los diversos grados jerárquicos que van desde la suprema potestad del Romano Pontífice hasta el Obispo diocesano - el fundamento ontológico, tanto del oficio, como de la potestad episcopal. Más concretamente, se debe sostener que existe un núcleo esencial e interno (innererWesenskern) sin distinción de orden y jurisdicción. Me parece que este núcleo esencial se puede individuar en la configuración personal (personalePrägung) del Obispo, y en particular en el poder indeleble y siempre eficaz (aunque en modo absoluto no sea lícito ejercitarlo) de conferir las órdenes sagradas, de modo que sean garantizadas la indefectibilidad y la ininterrumpida permanencia de la sagrada potestad en la Iglesia. (Mörsdorf, 1967, p. 54)

The great distinction point between MORSDORF and BERTRAMS will essentially be at the end. Even though the former shares the idea of the unity of the sacra potestas, he cannot accept the distinction and the classification according to the functions of teaching and sanctifying in the power of order and the function of ruling in the power of jurisdiction (Garroté, 1997, p. 262). For the German author, the three will be present in both powers.

\section{The Bipartion of the Jurisdiction}

On the other hand, we find an opposed position that will propose a gradual but clear division of the iurisdictio, and whose school will be led by STICKLER. According to this author, during its first centuries the Church did not delve into the concept of jurisdiction, being absolutely impossible to differentiate both powers in the ecclesial reality of the world (Cattaneo, 1986, p. 149). However, the heretic positions that flourished when the Church was trying to understand the Revelation will finally make effective such division that was not proper of the ecclesiastic world.

As we did previously, we can summarize in three points the reasons why, in his opinion, there is only one indistinctive concept of power (Stickler, 1975, p. 47).

Firstly, in a similar way of what happened in Roman Law, the Church did not divide power at all (Stickler, 1975, p. 49). As we have noted, from the gradual unification of powers in the figure of the Emperor, the power directly assumed the potestas, the authority and the empire. If the Church inspires itself in the roman juridical sources in those moments in which is starts little by little to organize it and obtaining a specific articulation, the Bishop, logically as an equivalent figure to the supreme power of the emperor, assumes all powers (Garroté, 1997, p. 311). We should add the fact that the same person exercising the tria munera is directly the divine will:

el Divino Fundador de la Iglesia quiso que fuesen confiados los oficios de magisterio, sacerdotal y de gobierno a una y a la misma persona del pastor» Es una realidad que remite así al derecho divino y que da lugar a una organización «sin aquella división de potestades que por todas partes en los modernos Estados se afirma del sistema de gobierno democratico. (Stickler, 1982, p. 68) 
If this first reason can be considered as positive, the next one will have a negative character: the Church did not have the necessary means to elaborate such a doctrine (Stickler, 1975, p. 47). Some centuries were needed to pass until the born of canonical science, in order to the Church could make their people understand the terms and the doctrine able to encompass such position (Stickler, 1982, p. 67). Then, lacking developed methods to solve diverse conflicts, means at its reach will be used to answer any kind of concern, based always in the artistic sources and those of the dogmatic science (Garroté, 1997, p. 270). In fact, during this period, those priests guilty of heresy must have been ordinate again, without any distinction of validity o unlawfulness. Augustine will be the one who firstly raises his voice to acknowledge the validity of the sacraments administered by the heretic ones, opening a path fo the future theological expression ex opera operato (Stickler, 1982, p. 54).

Finally, STICKLER adduces a juridical argument: in some occasions, for instance in what is known as the relative ordination, in order to be able to carry out a specific office, the Church will give the faculties to exercise it, clearly differentiating it from the absolute ordination:

la llamada ordenación relativa, para un concreto oficio de una determinada Iglesia (...) Consistía en otorgar todas las facultades propias del oficio al mismo tiempo que el orden (...) Toda otra ordenación sin una eficacia concreta, la llamada ordenación absoluta, estaba estricta y conscientemente rechazada y si tenía lugar era declarada directamente írrita, ineficaz (Concilio de Calcedonia, a. 451, can. 6) (...) Esta terminante prohibición no daba pie para una investigación positiva más detallada. (Stickler, 1982, p. 47)

Therefore, it is seen how in the canonical law it was not possible to separate ordination and office since they were two realities so intimately linked that the doctrine was not able to distinguish them (Stickler, 1975, pp. 67-68). In fact, and followingthewords of GARROTE:

No se distinguían los requisitos para ordenarse y, por otra parte, para desempeñar el oficio; las facultades provenientes de la consagración sacramental y del oficio confiado; por fin, la potestad derivada del orden y de la colación del oficio. El superior tenía una única potestad en razón de la sagrada ordenación y, en consecuencia, del oficio eclesiástico encomendado. (Garroté, 1997, p. 271)

Although, according to what has been exposed, it seems that we could affirm the inexistence of a diversity of powers during the first centuries, STICKLER himself will accept the existence of a diversity of powers, fundamentally from a practical point of view, mainly from the Augustinian texts against the ordained donatists, "entre el sacramento del orden y su ejecución o ejercicio por los citados donatistas, declarando válido aquél -el sacramento-, e inválidoéste - suejercicio-" (Stickler, 1975, p. 67). That is the way in which it is produced a distinction between the ordination, valid an comparable to the sacred power, and its exercise, comparable to the power of order and, in this case, invalid (Garroté, 1997, p. 301).

According to STICKLER, there are many examples we can find in the first millennium that make a difference, even though it is not reflected in the doctrine, it will do so in the practice: "distinction facti apparet inter ptestatem officii (regiminis) et potestatem personae (ordinis), quam vis doctrina distinctionis ad huc desideretur" (Stickler, 1975, p. 69).

There will be some moments in which there will exist a power of jurisdiction and not the other one, in the same way we will have the contrary, and also some cases where there a different power of jurisdiction even having the same power of order. STICKLER will conclude that, in the Church, there are some practices and institutions that underline the fact that, even the doctrine had not reflected on that situation and, therefore, being 
completely aware of this distinction, already existed in practice. Moreover, in not, it could have not been possible the reflection on a nonexistent object (Stickler, 1982, p. 71).

Then, and to conclude, we can assert that in the first period of Christianity, together with the power of order, obtained with the sacred order, the Church assumes little by little a new power related to the government of the faithful, and based on the division of jobs it was not bound to the person who carried it out (Stickler, 1975, p. 67).

\section{Conclusions}

As we have seen, Church and Empire, inseparable since the acceptance of the former by the latter, will be the touchstone for a mutual understanding. The potestas sacra that usually accompanied the emperor will have a new figure, the bishop, who as long as Christianity is expanded will claim as own the exercise of what is sacred.

However, both will assume little by little that reality, only one as the power who ruled it up to that moment, could be divided into two parts, a spiritual one and a temporal one. Therefore, and given that the Church was still becoming aware of itself, during the first centuries it will not develop the concept of iurisdictio, something that hindered, even made impossible, the possibility of differentiating the sacred and jurisdictional powers of the ministers, since their acts and not their conscience will be classifiable.

Then, the Church will be a structure inside a structure, reflecting the temporary realities it knew in order to give them a spiritual sense: in this way, learning from roman juridical sources, much more evolved, the articulation of the Church will usually copy the imperial structure, being all powers assumed by the Bishop.

Thus, there will be some moments in which a jurisdictional work is developed but not with a sacred character, and, in other moments, in which even possessing the same sacred order, the same jurisdiction will not be possessed.

On the other hand, it will not be easy to differentiate the ecclesiastic authorities from the civil dignities, since in many cases they will coincide or will little by little having ties as close as blood itself. Thus, different confrontation will arise, in which the Church will demand the necessary space to accomplish with the mission given by its founder, leaving aside the interferences of the temporal power. This vindication, whose first trace will be the conflict between Pope Gelasius and the Emperor of Byzantium, implied at the same time some problems: obviously, even though the freedom claimed by the Pope is only related to the spiritual problem, it is also true that the consequences were so many that stopping the influence in such decisions was a real danger for the civil rulers.

With the passage of time, feudal lords had to maintain an apparent unity at the same time, since all were part of the res publica christiana; whose unity was fundamental to face the uncertainties of the moment.

Probably the highest peak of this difficult situation and of the weak balance of the relations between the Church and the State is found during the XIth century. Pope Gregory will carry out a deep reform whose object will be, on the one hand, the reorganization of the external relations of the Church with the political power, reaching the desired independency of the Emperors of the Holy Roman Empire, dedicating itself exclusively to the Christian message; and on the other hand, the organization of the internal relations, centralizing the papal authority and strengthening the ecclesiastic government before situations that weakened the received message as well as the transmitted example. 


\section{References}

Arqulliere, H. X. (1965). L'augustinisme politiqueo Essai sur la formation des théories politiques du Moyen Age. París: Librairie Philosophique J. Vrin.

Baus, K., Beck, H. G., Ewig, E., \& Vogf, H. J. (1972). La Iglesia Imperial después de Constantino hasta finales del siglo VIII. In Jedin, E. (ed.) Manual de Historia de la Iglesia (Trad. De D. Ruiz Bueno). Barcelona: Herder.

Belda Iniesta, J. (2012). La donation constantini y los dictates papae como hitos de las relaciones Iglesia-Estado. Valencia: UCV.

Belda Iniesta, J. (2015). El ministerio judicial del obispo hasta el surgimiento de la lex christiana (ss. I-IV). Anuario de Derecho Canónico, 4, 387-401.

Belda Iniesta, J. (2016). The pleasure of privacy: Confession and inquisition as means to cause the correction of sinful consciences around the IV Lateran Council. Journal on European History of Law, 7(1), 54-59.

Bertrams, W. (1965). De subiecto suprema epotestatis Ecclesiae. Periódica, 54, 173-232.

Castaños-Mollor, M. I. (1981). La secularidad en los autores cristianos de los dos primeros siglos. Pamplona: Eunsa.

Cattaneo, A. (1986). Questioni fundamentali della canonistica nel pensiero di Klaus Mörsdorf. Pamplona: Publicaciones de la UNAV.

Celeghin, A. (1985). Sacra Potestas: Quaestio post conciliaris. Periodica, LXXIV, 165-225.

Congar, Y. (1952). en Catholicisme, París.

Corecco, E. (1968). L'origine del potere di giurisdizione episcopale. Aspetti storico-giuridici e metodologico-sistematici della questione. La Scuola Cattolica, 96, 3-42.

Corecco, E. (1985). Estructura y Articulación del Poder en la Iglesia. Communio, 14, 64-75.

De La Hera, A. (1965). Posibilidades actuales de la teoría de la potestad indirecta. Revista española de derecho canónico, 19(57), 775-800.

De Lubac, H. (1952). Le pouvoir de l'Eglise en matière temporelle. Revue des sciences religieuses, 12(3), 329-354.

D'Ors, A. (1964). Autoridad y potestad. en Lecturas jurídicas, 21, 23-35.

Fabrini, F. (1978). "Auctoritas", "Potestas" e "Iurisdictio" in Diritto Romano. Apollinaris, 51, 492-561.

Festugiere, A. J., \& Fabre, P. (1955). Il mondo greco-romano al tempo di Gesù Cristo. Turin: SocietaEditriceInternazional.

Garcia Villoslada, R. (1963). Historia de la Iglesia Católica, Vol. I. Madrid: Biblioteca Autores Cristianos.

Garroté, L. J. (1997). Existencia y ejercicio de la potestad de jurisdicción del Obispo en los siete primeros siglos. Pamplona: Publicaciones de la UNAV.

Leclero, J. (1959). L'idée de la royauté du Christ au Moyen Age. París: Editions du Cerf.

Lo Grasso, J. B. (1939). Ecclesia et Status. Roma: The Gregorian University Press.

Maccarrone, M. (1940). Chiesa e Stato nellad ottrina di papa Innocenzo. Roma: Pontificium Athenaeum Lateranensis.

Maritain, J. (1947). Primacía de lo espiritual, trad. esp. Buenos Aires: Club de Lectores Buenos.

Martínez Blanco, A. (1994). Derecho eclesiástico del Estado. Madrid: Tecnos.

Mato Ortega, J. M. (2003). Las dos espadas, Resumen crítico de: Historia del Pensamiento Político en la Edad Media. UbiSunt, 12, $20-24$.

Maymot, P. (1997). La episcopalisaudientia durante la dinastía teodosiana. Ensayo sobre el poder jurídico del obispo en la sociedad tardorromana. En Teja, R. and Pérez González, C. (Eds), Actas del Congreso Internacional La Hispania de Teodosio I (pp. 165-170). Salamanca: IE Universidad.

Mommsen T. \& Meyer, P. M. (eds.). (1990). Codex Theodosianus, 27, vol. I, p. 2. Hildesheim: Weidmann.

Mörsdorf, K. (1967). De sacra potestate: Quinquagesimovolventeanniversario a Codice Iuris Canonicipromulgato. Miscellanea in honorem Dini Staffa etPericlisFelici S. R. E. Cardinalium I. Apollinaris 40, 41-57.

Orlandis Rovira, J. (1999). Consideraciones en torno a la conversión al cristianismo en la tardía antigüedad.CHD 6, $233-243$.

Reina, V. (1966). La teoría de la potestas indirecta: precisiones. VII Congreso Internacional de Derecho Comparado (pp. 107-118). Uppsala: Servicio de Publicaciones de la Universidad de Navarra.

Reina, V. (1969). La Influencia romana en el derecho canónico como cuestión metrológica. IusCanonicum, 9/1, 179-220.

Reina, V. (1969). La Influencia romana en el derecho canónico como cuestión metrológica. IusCanonicum, 9/1, 179-220.

Riviere, J. (1962). Le probleme de I'Eglise et de l'Etat au temps de Philippe le Bel. Louvain-Paris: Dalloz.

Salegui Urdaneta, J. (2009). La potestad judicial en la diócesis. Cuadernos Doctorales, 23, 53-94.

Saraceni, G. (1951). La potestadella Chiesa in materia temporale e ilpensierodegliultimicinquePontefici. Milano: GiuffrèEditore.

Stickler, A. M. (1954). Sacerdozio e Regno nelle nuove ricerche attorno ai secoli XII e XIIIneiDecretisti e Decretalisti fino al/e 
decretali di Gregorio IX. Sacerdozio e Regno da Gregorio VII a Bonifacio VII, Roma.

Stickler, A. M. (1975). La bipartición de la potestad eclesiástica en su perspectiva histórica. IusCanonicum, 15.29, 45-75. Stickler, A. M. (1982). De potestatis sacrae natura et origine. Per, 71, 65-91.

Ullman, W. (1983). Historia del pensamiento político en la Edad Media. Barcelona: Ariel. 